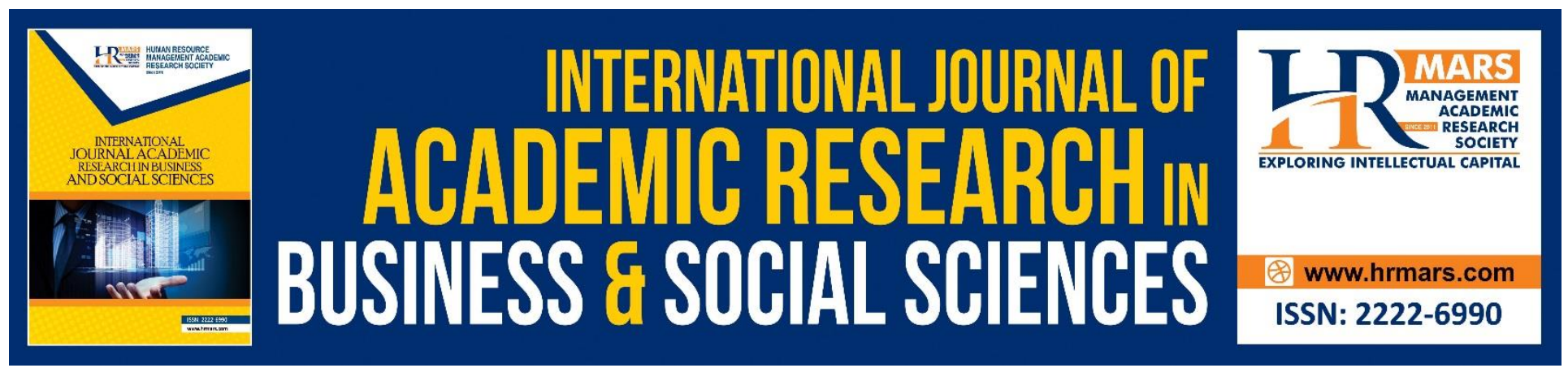

\title{
Conceptualizing Curriculum Evaluation in Education Degree Programmes in Higher Education Institutions
}

Rohaila Yusof, Khoo Yin Yin, Norlia Mat Norwani, Hartini Jaafar

To Link this Article: http://dx.doi.org/10.6007/IJARBSS/v8-i6/4299

DOI: $\quad 10.6007 /$ IJARBSS/v8-i6/4299

Received: 24 May 2018, Revised: 19 June 2018, Accepted: 29 June 2018

Published Online: 08 July 2018

In-Text Citation: (Yusof, Yin, Norwani, \& Jaafar, 2018)

To Cite this Article: Yusof, R., Yin, K. Y., Norwani, N. M., \& Jaafar, H. (2018). Conceptualizing Curriculum Evaluation in Education Degree Programmes in Higher Education Institutions. International Journal of Academic Research in Business and Social Sciences, 8(6), 1020-1033.

Copyright: (C) 2018 The Author(s)

Published by Human Resource Management Academic Research Society (www.hrmars.com)

This article is published under the Creative Commons Attribution (CC BY 4.0) license. Anyone may reproduce, distribute, translate and create derivative works of this article (for both commercial and non-commercial purposes), subject to full attribution to the original publication and authors. The full terms of this license may be seen at: http://creativecommons.org/licences/by/4.0/legalcode

Vol. 8, No. 6, June 2018, Pg. 1020 - 1033

Full Terms \& Conditions of access and use can be found at http://hrmars.com/index.php/pages/detail/publication-ethics 


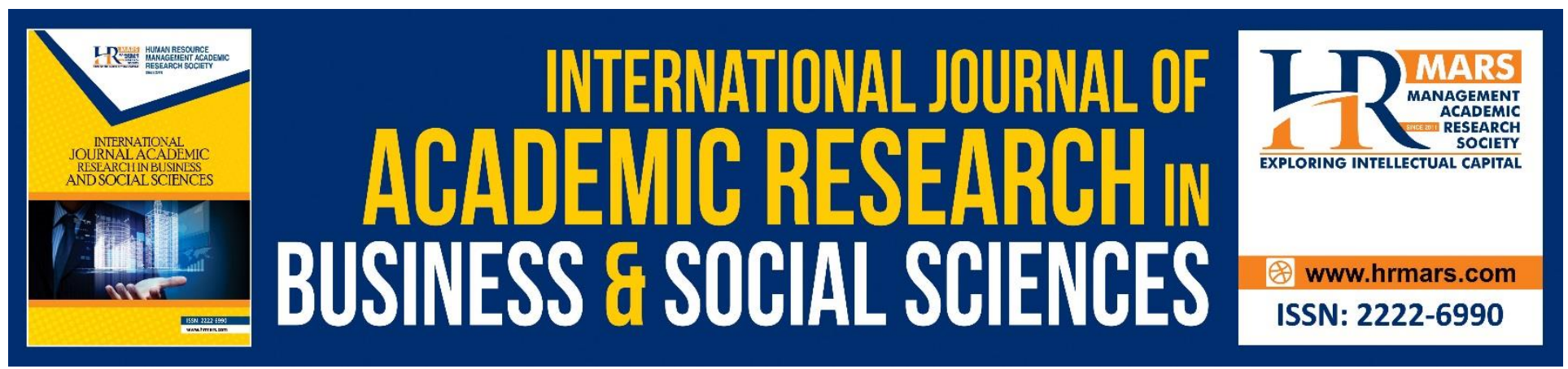

\title{
Conceptualizing Curriculum Evaluation in Education Degree Programmes in Higher Education Institutions
}

\author{
Rohaila Yusof \\ Faculty of Management and Economics, Universiti Pendidikan Sultan Idris \\ Email: rohaila @fpe.upsi.edu.my \\ Khoo Yin Yin \\ Faculty of Management and Economics, Universiti Pendidikan Sultan Idris \\ Email: khoo@fpe.upsi.edu.my \\ Norlia Mat Norwani \\ Faculty of Management and Economics, Universiti Pendidikan Sultan Idris \\ Email: norlia @fpe.upsi.edu.my \\ Hartini Jaafar \\ Faculty of Management and Economics, Universiti Pendidikan Sultan Idris \\ Email: hartini@fpe.upsi.edu.my
}

\begin{abstract}
Curriculum transformation in schools impacted the skills demanded on new teachers. The major changes in the curriculum is on the new students aspirations which focuses on the development of the $21^{\text {st }}$ century skills. Teachers' educational background, personality attributes, cognitive ability, students and teaching related skills are among the factors that affect the quality of teachers. These attributes and skills most part of it are developed through their university experience. Teacher education curriculum is considered effective only when it produces effective teachers at least as measured by the Malaysian Teacher Education Standards. To ensure continuous improvement in teacher education, curriculum evaluation at university level takes place with the awareness of the new needs, criteria and demands from stakeholders based on countries experiences. The curriculum evaluation leads to new curriculum development, preparing students with new skills, 21st century skills based on future needs (Ministry of Education, Malaysia, 2015). Curriculum evaluation in teacher education programme serve its own needs, the specific stakeholders, external and internal. Due to the differences in types, resources, curriculum structures and the numbers of the Institutions involved in teacher training, variation exists in the implementation of the teacher education curriculum in HEls. This paper conceptualizes the curriculum evaluation in teacher education programmes in HEls to suit the current demand for teachers. The study adapts the curriculum
\end{abstract}


INTERNATIONAL JOURNAL OF ACADEMIC RESEARCH IN BUSINESS AND SOCIAL SCIENCES Vol. 8, No. 6, June 2018, E-ISSN: 2222-6990 @ 2018 HRMARS

evaluation process using Stufflebeam's CIPP evaluation model. Each of the category context, input, process and output is represented by respective variables. The paper defines the concepts and models of curriculum evaluation introduced by past research and established theories. The dependent variable of this study is the 'product' labelled as quality and competitive graduates represented by the indicators of teacher professionalism from the Malaysia Teacher Standard. The competitive teacher graduates are measured through four dimensions of teacher graduates; the practice of professional teachers, the teaching skills, knowledge and understandings of educations philosophy and finally the leadership skills in teachers.

Keywords: Curriculum Evaluation, Education Degree, Higher Education.

\section{Introduction}

Higher Education Institutions (HEIs), are facing increasing demand by its stakeholders to produce competitive and quality graduates. Programmes offered in HEls are developed based on market needs, a measure to ensure higher rate of graduate employability. Various input factors are considered before any new programme is offered such as the compliance of curriculum structure, content and capacity to offer in terms of expertise, infrastructure, admission requirement and the sustainability of the programme in form of intake projections has to be realistic and competitive to comply with the Malaysian Qualification Framework (MQF). To ascertain the image and the quality of the new programmes offered, it has to be in line with the nature and niche of the particular HEl. Graduates unemployment is an ongoing issue facing the nation. It has become main agenda of the nation as government allocates more than RM20 million annually to train graduates to enhance their employability. Tracer studies done by MOHE in 2013, indicates only $47.6 \%$ of graduates are employed upon graduation, $19.9 \%$ intend to further studies and the rest are still unemployed at that point of survey. Quality of graduates have been widely researched and debated. Findings of previous studies on employers' feedback for various discipline areas are consistent. Skills which need improvement among graduates are communications and language, critical thinking, problem solving and decision making, and knowledge in current issues local and global (Hasbullah, Sharifah Mazlina \& Nur Affah, 2014; Shahrir, Dzuraidah \& Shafinza, 2012; Goi \& Ng, 2009), ability to apply knowledge and concept in workplace and diversity awareness skills (Goi \& Ng, 2009). PU are being criticized for not preparing graduates with the right skills and work ready.

The same predicament of graduate unemployment applies to graduate teachers though in different light. The demand for teachers is a closed market which comes from the Malaysia Education Ministry and partly from private schools. Curriculum transformation in school has some impact on teachers demand due to change in curriculum structure which involves changes in subjects and time allocation. Hence with so many providers of teacher education, it has become a competitive business. Due the competitiveness, teacher education programmes in Malaysia is highly sought after by school leavers, providing the providers opportunity to choose from the best. Teaching profession is a respectable profession due to their importance and their status in society. To ensure production of quality graduate teachers, various measures and selection criteria are introduced, stringent entry requirements starting with personality test, high academic achievement and interview process. The quality of teachers is reflected by students' performances, thus teachers need to be equipped with the relevant pedagogical and assessment skills. Currently, the Ministry of Education (MOE) is conducting curriculum reform which emphasizes on tasks and activity based classroom approaches (Siti Rafiah, Sharifah Sariah \& Nik Ahmad, 2012). This is in line with the current trend in teaching and learning which increases students' involvement to enhance students' higher order thinking. 
Information technology (IT) skills is compulsory for teachers to improve the efficiency of curriculum delivery (Siti Rafiah et al., 2012), According to Harris and Rutledge (2007), the quality of teacher graduates depend on their effectiveness in pedagogical skills and positive attitudes. Similarly, educational background, personality attributes and cognitive ability are the factors that affect the quality of teacher (Khojastehmehr \& Takrimi, 2009). Teacher personality will give impact on student performance, instructional and student achievement is affected by the personality traits of the teachers (Polk, 2006; Danili \& Reid, 2006; Ozel, 2007). There are various problems associated with curriculum implementation among others are managerial challenges in Iran, that is the competences and qualifications of managers involved (Marziyeh, Hamideh \& Hossein, 2011), feedbacks by students and faculty members that the curricular they studied did not match scientific development, economic, social and cultural development around them and the centralized organization structure (Vaziri, 1999).

Teacher education has multiplier impact on the quality of the students' learnings in school (Barber \& Mourshead, 2007). According to Sapie Sabilan et al. (2011), educators need to improve their knowledge by learning the new things so that the concept of lifelong learning should be applied. Dunkin and Biddle (1974), Atan (1978) and Mustaqim (2001) describe an important component is the teaching skills, applying strategies and teaching methods according to the level of knowledge and intelligence of the students (Anuar, 2015), which is different for each environment due to specific characteristics such as culture and historical background. The methods can be utilised in each different environment considering it is adapted to local characteristics (Edson, 2012). Popham (1975) suggested that the process lecturers can use in business education area are the needs of the learner and the needs of the business. Besides that, communication skills, case study, co-operative learning and individual versus teamwork task are some of lecturers' methods teaching (Zaid \& Abraham, 1994; Mc Laren, 1990; Campbell \& Lewis, 1991; Ravenscroft et al., 1995; Daroca \& Nourayi, 1994).

\section{Curriculum Evaluation}

Evaluation is a term applied in many ways with almost the same meanings. Evaluation is a bigger concept than measurement. It is fundamentally concerned with deciding the value or the worth wholeness of a learning process as well as the effectiveness with which it is being carried out (Bhavard, 2010). Past studies has conceptualized curriculum improvement for the purpose of course improvement, decisions about individuals or students, and administrative regulations. In current practice, curriculum evaluation has always been for monitoring and course improvement. Evaluation can be done throughout the study year or it can take place at the end of a specific period. The former is referred to as formative assessment which is considered as developmental, providing feedbacks for educators for necessary improvement in T\&L. The latter is termed as summative assessment, with wide coverage of content areas, which the results can be used for making on the curriculum evaluation. Various inputs affect the quality of graduates produced, many of them being the fact of the quality of educators, infrastructure, and quality of student's inputs are frequently considered as a priority that is the execution of a curriculum. Curriculum is defined as to fulfil the changing needs of a dynamic society through education. The curriculum links the selected educational goals and content with the micro, the act of teaching and assessment in the classroom/school, and is best seen as a series (Bhavard, 2010; 72).

Curriculum evaluation refers to the process of studying the merit or worth of some aspect, or the whole of a curriculum (Bhavard, 2010; 72). Curriculum evaluation reviews, monitors and reports on the quality of education to respective stakeholders. Stakeholders such as the public, 
INTERNATIONAL JOURNAL OF ACADEMIC RESEARCH IN BUSINESS AND SOCIAL SCIENCES Vol. 8, No. 6, June 2018, E-ISSN: 2222-6990 @ 2018 HRMARS

educators, students and government are the concerned parties effected by the decision made on a curriculum. Evaluation of curriculum is done to evaluate the system rather than an individual child. Content standard tell us what we want the students to know and what we want them to be able to do. The critics on content standards is their limited ability to improve students' achievement because they do not tackle the crucial questions of performance. Aligned performance measures are therefore necessary (Solomon, 2009). Effective curriculum change and implementation requires time, personal interaction, in-service training, and other forms of people-based support (Fullan, 1992). Effective curriculum assessment needs to gather and analyze information from multiple sources (Wolf, Hill \& Evers, 2006). An achievement of national objectives and keeping the system update respect to changing scenario of time is one of the direction of young generation on the desired way for the achievement and evaluation is the process of curriculum development. Curriculum evaluation is made with the new needs, criteria and demands from stakeholders based on countries experiences, the curriculum evaluation leads to new curriculum development, preparing students with new skills, $21^{\text {st }}$ century skills based on future needs (Ministry of Education, Malaysia, 2015). Curriculum development process also undergoes transformation due to newer development in education and its evaluation keeps it valid, reliable and keeps it in the right direction (Afzaal, Ashiq, Muhammad Azeem \& Azra, 2011; 263). Findings of curriculum evaluation from past research revealed mixed outcomes of curriculum implementation, in some developing countries, an official textbook and teacher guides is a sole resource used by teachers in teaching where the curriculum is the key reference point for teachers (Westbrook et al. 2013). In some cases substandard educational goals, materials and methods of instructions are not retained but up-dated in consonance with the advances in social cultural \& scientific field (Afzaal et al., 2011).

Concept of curriculum evaluation used to be very fundamental such as the basis of evaluation, its functions, the objects of evaluation, the variables to be investigated, criteria used, audiences served, the evaluation process, methods of inquiry, the qualification of evaluator and the standards for judgement of merit (Nevo, 1983). New students attributes to match the $21^{\text {st }}$ century demand requires reconceptualization of curriculum design and evaluation. Taking in the insight of Education 4.0 which is referred as education revolution, new themes in curriculum emerged. The concepts of university rankings, liberal education, industry partnership, flexibility in delivery, program recognition, and even new terms of pedagogy such as paragogy and heutagogy, new delivery technique such as gamification, project based and work-based learning and others are being introduced. Some HEs has managed to institutionalize these factors by designing new programs, encouraging Massive Open On-line Courses (MOOC), providing incentives to faculty members for innovation in course delivery. Thus, this new line of curriculum objective and implementation requires new concepts in curriculum evaluation. University and subject rankings, graduate employability, graduate attributes, employers' feedback, peer review, industry involvement, recognition and accessibility of academic courses, program accreditation, educators' professionalism, graduates career path and the breadth and width of the curriculum all become the new criteria in curriculum implementation. At micro level, process such as curriculum mapping takes place in order to ascertain the alignment of all the factors involved in curriculum implementation in achieving the program outcomes. Challenges in choice of courses to fulfill the academic structure happens all the time due to political, economic and social demand. At the same time there are many inherited challenges in curriculum review in HEs posed by their own structure. New emphasis on faculty to embrace ownership of curricular at the degree program level not just at the course level (Myers, 2006). 
INTERNATIONAL JOURNAL OF ACADEMIC RESEARCH IN BUSINESS AND SOCIAL SCIENCES Vol. 8, No. 6, June 2018, E-ISSN: 2222-6990 @ 2018 HRMARS

Curriculum development process also undergoes transformation due to newer developments in education and its evaluation keeps it valid, reliable and keeps it in the right direction thus to differentiate educational institutions and interpret situations a given or prescribed curriculum takes place (Afzaal et al., 2011). For example in Greece, Vangelis (2009) mentions the importance of curriculum evaluation in which the new curriculum development is a new chapter for Greek education where all the new community programs should be evaluated based on criteria and processes as detailed in each of their respective objectives.

The choice of curriculum evaluation model depends on the objective of the evaluation. Generally the major aspects of a curriculum to be analysed is the objective of the academic program, the content discipline area, delivery and assessment (Wolf, Hill \& Evers, 2006), concerns on the usage of the collected information, the effective timing for the evaluation process, who are responsible for providing information and what are the feedback methods to be used during the evaluation process. Curriculum implementation refers to the aspects of it is objectives, contents, presentation and assessment of a curriculum. Hence, curriculum implementation refers to the overall experience students had gained throughout their stay in the university, while curriculum implementation is defined as a curriculum plan conducted by the name of courses and syllabus. It is a process that helps students to gain both knowledge and experience. Curriculum evaluation is an establish discipline area which is supported by different evaluation models which serve their own purpose. Various curriculum models have been introduced such as Bradley's effectiveness model, Tyler's objective oriented model, Stufflebeam's CIPP Model, Scriven Goal Free Model, Model of responsive stake and the Roger's model.

Using the CIPP approach helps in identifying the needs of the university through the manifestation of mission, vision and objectives of an Institution. Assessment of inputs describes the uptake in the provision of human resources in terms of expertise, student input quality and compliance requirements that need to be met in the implementation process and its relevance to the process of implementation of academic programs. The components of the program implementation process include the curriculum content, the effectiveness of the assessment system and the effectiveness of Teaching and Learning (R \& D) taking into account the needs of the lecturers. Finally, product components measure the capabilities of teachers who produce by the Institution in the areas of professional value practice, T\&L skills, understanding and knowledge of the educational philosophy and leadership skills that are formed. The contextual objective of the assessment is to assess the extent to which the vision, mission and goals of the university are in line with the needs (Cuba \& Stufflebeam, 2003). Input assessment explains the need for improvement to make the necessary changes. In the input assessment, relevant stakeholders such as students, faculty, employers and coworkers can be encouraged to review the program improvements offered. The program implementation process assesses the extent to which programs have been implemented effectively. Product evaluation identifies and evaluates program outcomes planned and out-of-planned outcomes. The four components of the CIPP model can be used effectively at different level of decision makings in curriculum evaluation; context for planning, input for structuring, process for implementation and product for the recycle process. 
INTERNATIONAL JOURNAL OF ACADEMIC RESEARCH IN BUSINESS AND SOCIAL SCIENCES

Vol. 8, No. 6, June 2018, E-ISSN: 2222-6990 @ 2018 HRMARS

Table 1: Stufflebeam's CIPP Evaluation Model

\begin{tabular}{l|l}
\hline Level of evaluation & Classification in decision- making \\
\hline Context & Planning \\
Input & Structuring \\
Process & Implementation \\
Product & Recycle process \\
\hline
\end{tabular}

The Tyler Curriculum Model (1949) is based on both objective and process. In his book entitled Principles of Curriculum and Instructions, he has defined the curriculum which is the lesson planned, implemented and operated by the school to achieve the stated goals of education. He stated that the objectives of the lesson should have two (2) related aspects namely the development of student's own behavior and the content of subjects that operate with student behavior. In addition, Tyler (1949) also sees that with the statement of educational objectives in a curriculum the teacher will be able to plan the learning outlined in a curriculum that has been stated. He proposes four main points that need to be included in the curriculum, that is, matters and activities that need to be done by topic lecturers and concepts for each subject should be listed, the behavior along with its developmental objectives should be stated in each subject topic, as well as the learning objective expressed in a clear objective form in order to be a lecturer guide to produce student behavior change.

Table 2 shows the curriculum evaluation models. The researcher focuses on three curriculum evaluation models. First is Tyler model where it is focus an attention on the strengths and weaknesses of the curriculum, not merely in respect of the performance of individual students and stressing the importance of a continuous cycle of assessment, analysis, and improvement. While, CIPP model build and equip all the information to produce a variety decision, help audiences make decisions and build educational program or something useful, build and equip a number of policies and programs and getting the formative and summative in decision-making and problem-solving ability. Last but not least is Goal-Free Scriven Model where the purpose of model is assessing the effectiveness of a program, promoting the actual effect of a program of the expected impact, defining relationships and a good alternative for a product and service of education and determine the overall benefits of a program to ensure that all users of the program impact. The similarities of these models is focus on the content in a curriculum or program in which the results of the assessment and be able to help solve the problem. In addition, to ensure a curriculum or program may have an impact on students and the assessment will be based on student achievement. Literiture on a few evaluation models is analysed to get a wider view of the variables involved. Namely three (3) big models are reviewed;

I) Tyler Model

II) CIPP Model

III) Goal-free Model 
INTERNATIONAL JOURNAL OF ACADEMIC RESEARCH IN BUSINESS AND SOCIAL SCIENCES Vol. 8, No. 6, June 2018, E-ISSN: 2222-6990 @ 2018 HRMARS

Table 2: Curriculum Evaluation Models

\begin{tabular}{|c|c|c|c|}
\hline Model & Purpose & Indicator & Evaluation Process \\
\hline Tyler Model & $\begin{array}{l}\text { Focus attention on the } \\
\text { strengths and } \\
\text { weaknesses of the } \\
\text { curriculum, not merely } \\
\text { in respect of the } \\
\text { performance of } \\
\text { individual students. } \\
\text { Stressing the } \\
\text { importance of a } \\
\text { continuous cycle of } \\
\text { assessment, analysis, } \\
\text { and improvement. }\end{array}$ & 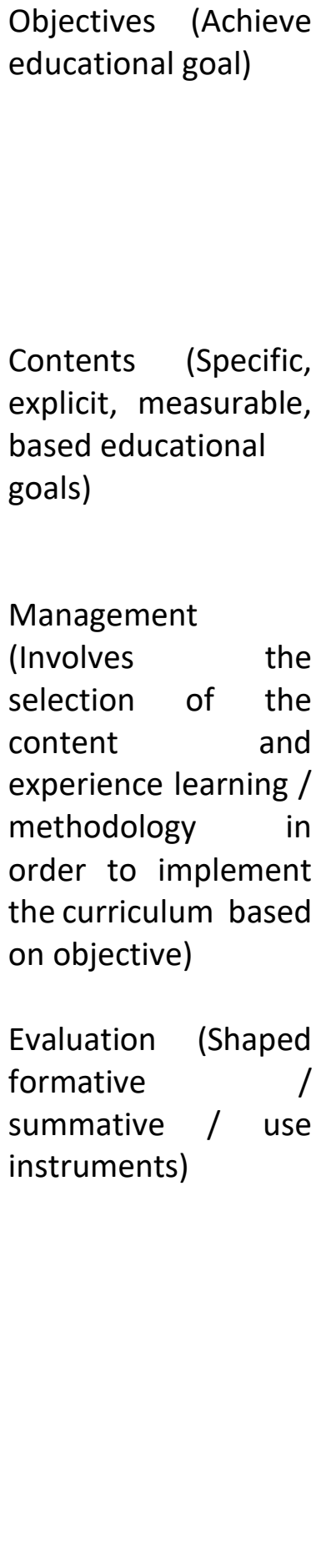 & $\begin{array}{l}\text { Select, modify, / } \\
\text { architecture } \\
\text { appropriate } \\
\text { assessment } \\
\text { instruments, and } \\
\text { shrubs instruments } \\
\text { for objectivity, } \\
\text { reliability, and } \\
\text { validity. } \\
\text { Use the instrument } \\
\text { to get the results } \\
\text { that are } \\
\text { summarized } \\
\text { evaluated. } \\
\text { Compare } \\
\text { results that were } \\
\text { obtained. } \\
\text { Analysis of results } \\
\text { to make the } \\
\text { decision to modify }\end{array}$ \\
\hline CIPP Model & $\begin{array}{l}\text { Build and equip all the } \\
\text { information to produce } \\
\text { a variety decision. }\end{array}$ & $\begin{array}{l}\text {-Contexts } \\
\text { (Constantly assessing } \\
\text { the needs and } \\
\text { problems in context } \\
\text { to help decision- }\end{array}$ & $\begin{array}{l}\text { Type of decision } \\
\text { identified. }\end{array}$ \\
\hline
\end{tabular}




\begin{tabular}{|c|c|c|c|}
\hline & $\begin{array}{l}\text { Help audiences make } \\
\text { decisions and build } \\
\text { educational program } \\
\text { or something useful. } \\
\text { Build and equip a } \\
\text { number of policies and } \\
\text { programs } \\
\text { Getting the formative } \\
\text { and summative in } \\
\text { decision-making and } \\
\text { problem-solving } \\
\text { ability. }\end{array}$ & $\begin{array}{l}\text { makers determine } \\
\text { the goals and } \\
\text { objectives) } \\
\text {-Input } \\
\text { (Evaluate alternative } \\
\text { ways to achieve the } \\
\text { goal of helping } \\
\text { decision-makers } \\
\text { choose the optimal } \\
\text { way) the } \\
\text {-Process } \\
\text { (Monitor both the } \\
\text { process to ensure } \\
\text { that the way is } \\
\text { actually } \\
\text { implemented and to } \\
\text { make the necessary } \\
\text { modifications) } \\
\text {-Product } \\
\text { (Measuring the } \\
\text { outcomes in terms of } \\
\text { the initial aspirations) }\end{array}$ & $\begin{array}{l}\text { The type of data } \\
\text { needed to make } \\
\text { decisions is } \\
\text { identified. } \\
\text { collected } \\
\text { They criteria for } \\
\text { data. } \\
\text { The the } \\
\text { determining } \\
\text { quality established. } \\
\text { dhe were } \\
\text { analyzed based on } \\
\text { their criteria. } \\
\text { Information can be } \\
\text { provided to } \\
\text { decision makers. }\end{array}$ \\
\hline $\begin{array}{l}\text { Goal-Free } \\
\text { Scriven Model }\end{array}$ & $\begin{array}{l}\text { Assessing the } \\
\text { effectiveness of a } \\
\text { program } \\
\text { Promoting the actual } \\
\text { effect of a program of } \\
\text { the expected impact } \\
\text { Defining relationships } \\
\text { and a good alternative } \\
\text { for a product and } \\
\text { service of education } \\
\text { Determine the overall } \\
\text { benefits of a program } \\
\text { to ensure that all users } \\
\text { of the program impact }\end{array}$ & $\begin{array}{l}\text { Identify effectiveness } \\
\text { program } \\
\text { Identify the } \\
\text { relationship between } \\
\text { cause and effect } \\
\text { Checklist of } \\
\text { evaluation (The Key } \\
\text { Evaluation Checklist) } \\
\text { Independent } \\
\text { assessment of goal } \\
\text { Needs assessment } \\
\text { Features appraisers }\end{array}$ & $\begin{array}{l}\text { Observations in the } \\
\text { classroom }\end{array}$ \\
\hline
\end{tabular}


INTERNATIONAL JOURNAL OF ACADEMIC RESEARCH IN BUSINESS AND SOCIAL SCIENCES Vol. 8, No. 6, June 2018, E-ISSN: 2222-6990 @ 2018 HRMARS

\begin{tabular}{|l|l|l|l|}
\hline & $\begin{array}{l}\text { Data collection } \\
\text { techniques } \\
\text { Evaluation results }\end{array}$ & $\begin{array}{l}\text { Tests } \\
\text { examinations }\end{array}$ \\
\hline
\end{tabular}

The three models consists of almost similar variables which are packaged into different headings. Tyler's model emphasis on objective achievement which is applicable in current situation even in the latest outcome-based education models. The other three (3) elements; content, delivery and assessment are the actions taken to fulfil the objective. CIPP model on the other hand look into a wider scenario of curriculum evaluation which includes the context of the curriculum implementation. This is a significant factor for teacher education curriculum evaluation in Malaysia considering emerging issues in teachers' skills and preparedness. New aspirations affects curriculum and school subjects, assessment strategies and students outcomes. Skills which are not given enough emphasis during training could be the ones highly sought after. Take education 4.0 as a challenge, are student teachers ready with the new needs such peer learning strategies, self-determined learnings and flexible delivery methods. The other three elements in CIPP are inputs, process and product. These three elements justifies the fairness in evaluation after measuring the products against the context, input and process.

Piaget's theory of sequential stage of cognitive and moral development emphasized on knowledge construction, therefore the curriculum should provide experience-rich environments that promote opportunities to learn with as active participants, rather than teacher dominated environment. Interaction among peers should be encouraged. Technology should be used to provide the richest possible environment (Solomon, 2009). Piaget suggests that children learn when their thoughts are listened to and they receive a response (Solomon, 2009), this process takes place in cooperative learning. In line with the concept of constructivism, curriculum should be able to address students' prior knowledge and their goals. New perceptions are needed to create new knowledge. Any new information can only fit in if it meets the needs of existing knowledge, goals and attitudes. Prior knowledge, new perceptions and goals are necessary factors in creating new knowledge (Solomon, 2009). Vygoysky (1978) put emphasis on the sociocultural context and the role of mediators, in his theory of cognitive development which is referred to under social constructivism. The concept of scaffolding, instructional mapping, cooperative learning are the application of the Vygotsky's 'zone of proximal development' and social constructivism. Suggested action by Solomon (2009) is to provide a learning environment that have multitude of experiences, and social interactions. Lessons should be planned on how to stretch students' knowledge across the 'zone of proximal development or construction', matched with identified environments, prior knowledge and planned outcomes.

Knowledge can be constructed individually or through social interaction. Curriculum content standards should consist of the knowledge of the consensual domain that educators judge as appropriate for the individual and learning situation, instructional process should be considered a way of building and correcting individual realities (Solomon, 2009). Human intelligence is a complex characteristics and influenced by many factors namely heredity and environment. Individuals vary in their ability in mastering the content and processing phases, there curriculum should reflect this variation among individuals in its supports of already existing ability and in further development of all abilities (Solomon, 2009). Memory is a factor to be considered in curriculum delivery. Short term and long term memory works best if activities provided are able to maintain students' attention. 
INTERNATIONAL JOURNAL OF ACADEMIC RESEARCH IN BUSINESS AND SOCIAL SCIENCES

Vol. 8, No. 6, June 2018, E-ISSN: 2222-6990 @ 2018 HRMARS

Curriculum activities should be able to combine memory categories, goal structuring, stimulates connections to prior knowledge.

\section{Conceptual Framework for Curriculum Evaluation in Education Degree Program}

This paper intends to conceptualize the curriculum evaluation of Accounting Education curriculum in an Education University. The first part of the study is to adapt the curriculum evaluation process using Stufflebeam's CIPP evaluation model. Each of the category context, input, and process output is represented by respective variables. The paper defines the concepts and models of curriculum evaluation introduced by past research and established theories. Figure 1 explains how the variables in this study fits the CIPP model for a comprehensive evaluation of the curriculum implemented. Context is represented by 3 dimensions; Firstly, the vision, mission, purpose, and objective of university and faculty, secondly the curriculum, structure content and teaching and learning. Lastly is the current situation in administration of new teachers in the country, among others is the issue of access of business and accounting teachers. Changes in secondary school curricular is effecting the allocation of time and number of takers for business and accounting subjects.

Input in this model is represented by the delivery of teaching and learning by the educators, students input factors which is related to the admission criteria, UPSI academic regulations on the technicalities of programme requirement, and lastly the Malaysian Qualifications agency requirement for programme accreditation. Process is represented by the curriculum consists of curriculum objective, content, teaching and learning and the support system. The dependent variable of this study is the product labelled as quality and competitive graduates represented by the indicators of teacher professionalism from the Malaysia Teacher Standard. Quality and competitive teacher graduates is measured through four dimensions of teacher graduates; the practice of professional teachers, the teaching skills, knowledge and understandings of educations philosophy and finally the leadership skills in teachers. Teacher leadership is new dimension extracted from Malaysian Education Blueprint (2013-2025). 


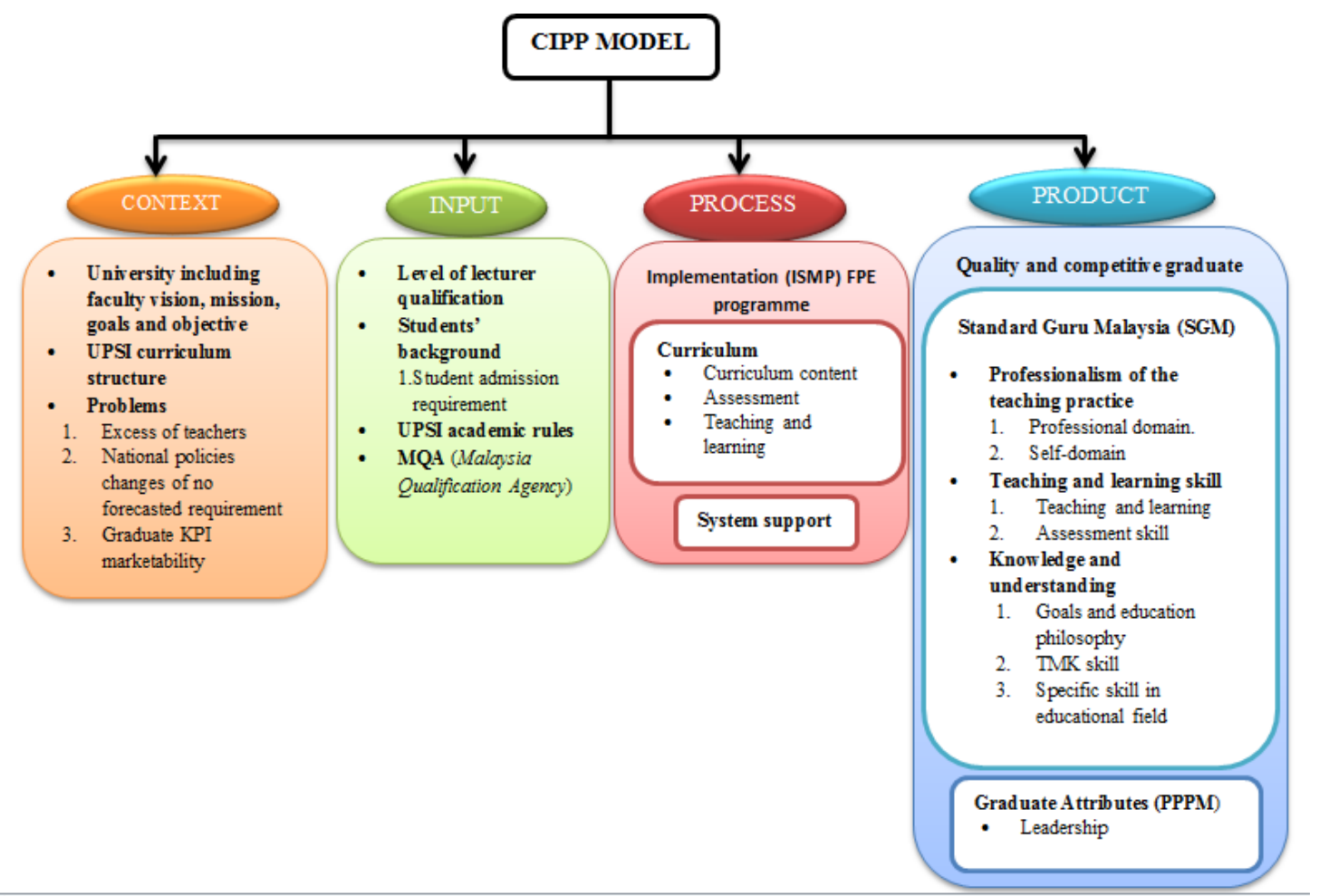

Figure 1: Conceptualizing curriculum evaluation using CIPP Model.

Context and input is assessed through document analysis according to respective variables. University documentation, faculty handbook and information from MOE is used to put the curriculum in context. Generally the curriculum of teacher education is found to be very relevant to UPSI vision "To be a prestigious university providing exceptional leadership in education, based on the advantage of broad experience and high level of competency in meeting global changes", and the mission is "to generate and foster knowledge through teaching, research, publication, consultancy and community services to achieve the vision of the nation". Students' entry requirement as stated in input is the minimum requirement stated by MOHE for entering PU. The rest of the input factors such as educators' competency and support system is gathered through students' response. Being a public university which is governed by the ministry regulation and procedures in general the context and input has been put in place.

\section{CONCLUSION}

As a conclusion all universities either public or private, need to adapt the curriculum to the latest needs and demand. The content of the curriculum for accounting education field should be in line with the outside world and the world in which traditional forms of curriculum content that is likely to be less relevant to the current situation. In addition, through the assessment of the students will prove that teaching and learning methods used by lecturers is suitable or not with the passage of time now. This is particularly evident when the students' performance decline and its impact on student achievement and the achievement of the university meeting the criteria set by authority. 
INTERNATIONAL JOURNAL OF ACADEMIC RESEARCH IN BUSINESS AND SOCIAL SCIENCES

Vol. 8, No. 6, June 2018, E-ISSN: 2222-6990 C 2018 HRMARS

\section{References}

Hussain, A., Ashiq, H. D., Azeem, M. \& Shakoor, A. (2011). Evaluation of curriculum development process. International journal of humanities and social science, 1(14), pp 263-271.

Ozel, A. (2007). The effect of Turkish geography teacher's personality on his teaching experiences. International journal of environmental and science education, 2(3), pp 75-78.

Bhavard, A. J. (2010). Curriculum evaluation. International Research Journal, 1(12), 72-74. ISSN0975-3486.

Ahmad, A. \& Jinggan, N. (2015).Pengaruh kompetensi kemahiran guru dalam pengajaran terhadap pencapaian akademik pelajar dalam mata pelajaran Sejarah. Jurnal kurikulum dan pengajaran Asia Pasifik, 3(2), pp 1-11.

Barber, M. \& Mourshead, M. (2007). How the world's best-performing school systems come out on top. London: McKinsey Company.

Campbell, J.E. \& Lewis, W.F. (1991).Using cases in accounting classes, Issues in Accounting Education, Fall, pg. 276-283.

Danili, E., \& Reid, N. (2006). Cognitive factors that can potentially affect pupils' test performance. Chemistry Education Research and Practice, 7 (2), 64-83.

Daroca, F. \& Nourayi, M.M. (1994).Some performance and Attitude Effects on Students in Managerial Accounting: Lecture vs. Self-Study Courses, 9(2), pp, 319-329.

Dunkin, Michael, J. \& Biddle, B.J. (1974). The study of teaching. New York: Holt, Rinehart and Winston, Inc.

Edson L.R. (2012).Teaching-Learning methods in accounting education-An empirical research in the Brazilian scenario.

Fullan, M.G. (1992). Successful School Improvement: The Implementation Perspective and Beyond. Milton Keynes: Open University Press.

Guba, E.G. and Stufflbeam, D.L. (1970). Evaluation: The process of stimulating, Aiding and Abetting Insightful Action in Smith, C.B (ed) Monograph series in Reading Education No. (1 June 1970). Indian University.

Harris, D.N., \& Rutledge, S.A. (2007). Models and predictors of teacher effectiveness: A review of the literature with lessons from (and for) other occupations. Madison, WI: Teacher Quality Research. Retrieved from http://www.teacherqualityresearch.org/models.pdf. 
INTERNATIONAL JOURNAL OF ACADEMIC RESEARCH IN BUSINESS AND SOCIAL SCIENCES

Vol. 8, No. 6, June 2018, E-ISSN: 2222-6990 @ 2018 HRMARS

Khojastehmehr, R. \& Takrimi, A. (2009). Characteristics of effective teachers: Perceptions of the English teachers. Journal of Education \& Psychology, 3 (2), 53-66.

Marziyeh, D., Hamideh, P. \& Hossein, J. (2011). Managerial challenges of curriculum implementation in Higher Education. Procedia Social and Behavioral Sciences 15(2011) 2003-2006.

Mc Laren, M.C. (1990). The place of communication skills in the training of accountants in New Zealand. Accounting and Finance, 30 pp, 83-94.

Mutasqim, H. (2001). Psikologi pendidikan. Yogyakarta: Pustaka Murid.

Myers, W.R. (2006). Essay: Academic program assessment and the academic dean. In ATS folio: Master of divinity curriculum revision (pp.34-40). Pittsburgh: Association of Theological Schools.

Nevo, D. (1983). The conceptualization of educational evaluation: An analytical review of the literature.

Polk, J. A. (2006). Traits of effective teachers. Arts Education Policy Review, 107(4), pp 23-29.

Popham, E.L., Adele, F.S. \& Wanda, B. (1975). A teaching, learning system for Business Education. McGraw-Hill Inc.

Solomon, G.S. (2009).The curriculum bridge: From standards to actual classroom practice. (3 rd. Edition). Corwin Press: California.

Vangelis, K. (2009). Curriculum evaluation in Greece. Journal of multidisciplinary education, 6(12), pp 177-191.

Vaziri, M. (1999). The curriculum development system in Iran's Higher Education: Characteristics and orientation. PhD Dissertation, Faculty of Humanities. Tarbiyat Modares University.

Vygotsky, L.S. (1978). Mind in society: The development of higher psychological processes. Cambridge, MA: Harvard University Press.

Westbrook, J., Durrani, N., Brown, R., Orr, D., Pryor, J., Boddy, J. \& Salvi, F. (2013). Pedagogy, Curriculum, Teaching Practices and Teacher Education in Developing Countries. University of Sussex.

Wolf, P., Hill, A., Evers, F. (2006). Handbook for curriculum assessment winter 2006.

Zaid, O.A. \& Abraham, A. (1994). Communication skills in accounting education: perceptions of academics, employers and graduate accountants. Accounting Education, 3, pp 205-221. 